\title{
A Systematic Review of Soft Tissue Alterations and Aesthetic Outcomes Following Immediate Implant Placement and Restoration of Single Implants in the Anterior Maxilla
}

\author{
Nabil Khzam, *† Himanshu Arora,* Paul Kim,* Anthony Fisher,* Nikos Mattheos, $\neq$ Saso \\ Ivanovski $^{*}$
}

*School of Dentistry and Oral Health, Griffith University, Gold Coast, QLD, Australia.

†University of Tripoli, Libya.

$\ddagger$ Faculty of Dentistry, University of Hong Kong, Prince Philip Dental Hospital, Hong Kong SAR, China.

Objectives: To assess the outcome of single tooth immediate implant placement and restoration (IPR) in the maxillary anterior region with a particular emphasis on soft tissue and aesthetic outcomes.

Material and methods: An electronic search in MEDLINE, EBSCOhost, and Ovid (PubMed) was performed to identify studies that reported on soft tissue outcomes following immediate placement and restoration of implants in the maxillary aesthetic region with a mean follow-up of at least 1 year.

Results: A total of 19 studies on single implants inserted immediately into a fresh extraction sockets and provisionally resorted in the maxillary aesthetic region were included. Soft tissue changes were found to be acceptable, with most studies reporting a mean gingival recession of $0.27 \pm 0.38 \mathrm{~mm}$ and mean papillary height loss of $0.23 \pm 0.27 \mathrm{~mm}$ after follow up of $\geq 1$ year. The incidence of advanced buccal recession $(>1 \mathrm{~mm})$ occurred in $11 \%$ of cases. The long term follow-up studies ( $>2$ years) reported that the interdental papillae, in particular, showed a tendency to rebound over time. The few studies that reported on patient centered outcome analysis showed a high level of patient satisfaction with the outcomes of IPR treatment.

Conclusions: The IPR protocol resulted in generally acceptable soft tissue and aesthetic outcomes, with sub-optimal results reported in approximately $11 \%$ of low risk cases. Factors like pre-operative tissue biotype, use of a flap or connective tissue graft did not significantly influence soft tissue and aesthetic outcomes. Long term prospective controlled clinical trials are necessary to identify factors which may influence the aesthetic outcomes associated with the IPR protocol.

\section{KEY WORDS:}

Dental Implants, Single Tooth; Esthetics; Maxilla, Prospective study, Patient Satisfaction

Dental implant supported restorations have become an acceptable, and often preferable, treatment option for tooth replacement in many clinical scenarios. ${ }^{1-3}$ The original implant treatment guidelines advocated a three month waiting period following tooth extraction to allow for soft and hard tissue healing prior to placing an implant, which was followed by an additional three to six month load-free period following implant placement to achieve osseointegration. ${ }^{4,5}$

Immediate implant placement into a fresh extraction socket has been advocated as a protocol that can reduce the treatment time as the socket healing and implant osseointegration occur concurrently. ${ }^{6,7}$ Immediate placement can further be combined with immediate restoration (IPR protocol), ${ }^{8}$ which provides the patient with a fixed restoration immediately following tooth extraction. The definitions of immediate placement and immediate restoration are based on widely accepted consensus reports. ${ }^{9,}{ }^{10}$ Immediate implant placement, also known as Type I placement, is defined as the placement of an implant immediately following tooth extraction, ${ }^{9}$ while immediate restoration has been defined as any restoration placed within 48 hours of implant insertion but with no contact with the opposite dentition in both centric and eccentric occlusion. ${ }^{10}$ 
The IPR protocol ${ }^{8,11}$ has a number of proposed benefits including reduced overall treatment duration, fewer surgical procedures for the patient, less traumatic surgery (as the implant may be placed without raising a flap), and patient satisfaction resulting from a fixed aesthetic restoration being placed immediately following tooth extraction. The limitations of this treatment protocol include the possibility of unpredictable soft and hard tissue healing, and subsequent unfavorable soft tissue and aesthetic outcomes.

Several published systematic reviews have shown that the IPR protocol can achieve comparable survival rates to that achieved with traditional protocols. ${ }^{11-14}$ In a recent systematic review on the IPR technique in the aesthetic zone, ${ }^{14}$ the authors reviewed all identified variables affecting the treatment outcome. However, the evidence regarding the soft tissues and aesthetic outcomes in patients treated with the IPR modality in the maxillary aesthetic zone is still inconclusive. With the increasing emphasis on implant success rather than survival, and the importance of patient centered outcomes in what is a very aesthetically sensitive region, it would be of significant clinical benefit to identify the effects of this treatment modality on the surrounding soft tissues, and its overall effect on aesthetic outcomes. Thus, the objective of this systematic review was to assess the soft tissue dimensional changes and the aesthetic outcomes of the IPR protocol when replacing a single maxillary tooth in the aesthetic region.

\section{MATERIALS AND METHODS}

\section{Search Strategy}

This systematic review was conducted in accordance with the Preferred Reporting Items for Systematic Review and Meta-analysis (PRISMA) guidelines. ${ }^{15}$ A detailed electronic search strategy was used for each selected database in order to identify all of the articles published in relation to the stated aims of this review. The searched data bases were: PUBMED, EBSCOhost and Ovid arms of MEDLINE, and articles were searched from 1980 - May 2015. The following search strategy was used: ((("dental implants"[MeSH Terms] OR ("dental"[All Fields] AND "implants"[All Fields]) OR "dental implants"[All Fields]) OR ("dental implants, single-tooth"[MeSH Terms] OR ("dental"[All Fields] AND "implants"[All Fields] AND "single-tooth"[All Fields]) OR "single-tooth dental implants"[All Fields] OR ("dental"[All Fields] AND "implants"[All Fields] AND "single"[All Fields] AND "tooth"[All Fields]) OR "dental implants, single tooth"[All Fields])) AND ("maxilla"[MeSH Terms] OR "maxilla"[All Fields])) AND (("tissues"[MeSH Terms] OR "tissues"[All Fields] OR "tissue"[All Fields]) OR ("esthetics"[MeSH Terms] OR "esthetics"[All Fields])).

Furthermore, the search was complemented by checking the references of the selected articles for additional eligible publications. In addition, a manual search was carried out of the major journals related to dental implantology (see supplementary Appendix 1 in the online Journal of Periodontology).

\section{Inclusion Criteria}

- Randomized controlled trials, controlled clinical trials, prospective cohort studies, case control studies and case series. Only prospective studies were included in this review

- Studies with a minimum of 10 human subjects treated with the immediate placement and restoration protocol in the maxillary aesthetic region (up to $2^{\text {nd }}$ premolar)

- A minimum mean follow up time of 1 year

- English publications in dental literature 
The following PICO strategy was designed to select the studies to be included in this review: ${ }^{16}$

Participants. Patients requiring a single implant in the maxillary aesthetic zone

Intervention. Implant placement using the immediate placement and immediate provisional restoration (IPR) protocol

Comparison. Soft tissues dimensions and the aesthetic and patient centered outcomes, before and after immediate placement and restoration in the maxillary aesthetic zone

Outcomes. Soft tissue dimensional changes and aesthetic outcomes

\section{Selection of Studies}

After the initial electronic search of titles by the first author, titles and abstracts of all studies identified via electronic searches were scanned independently by two reviewers (N.K. and P.K.). The next step was to review all selected abstracts to determine selection of full text articles after applying the inclusion criteria. The full texts of all studies of possible relevance were then obtained for independent review and assessment by the two reviewers.

Disagreements among reviewers were resolved by discussion. Kappa agreement between the two reviewers was 0.91 . All studies meeting the inclusion criteria then underwent data extraction. Studies rejected at this or subsequent stages were removed and reasons for exclusion recorded.

\section{Quality Assessment}

Methodologic quality of the included studies were assessed by two reviewers (N.K. and H.A.) using specific study design-related forms designed by the Cochrane Collaboration. Randomized controlled trials as well as prospective trials and case series were assessed and the risk of bias was recorded for every study using a modified checklist as described in a previous review (Table 1). ${ }^{17,18}$

\section{Data Extraction}

The data that were extracted are presented in supplementary Appendix 2 in the online Journal of Periodontology.

\section{Statistical Analysis}

$\kappa$ statistics were used to evaluate inter-examiner agreement on study eligibility and quality. The midfacial and papillary soft tissue changes from the included studies were extracted and pooled results presented as mean \pm SD. Individual study data was available to assess the effect of three variables namely: flap employment; tissue biotype; and use of connective tissue graft (CTG), on the soft tissue changes following the IPR techniques. Results from the included studies pertaining to these variables were pooled up and analyzed statistically using an unpaired t-test using Welch correction. A $P$ value $<0.05$ was considered to indicate statistical significance. 


\section{RESULTS}

\section{Study Inclusion}

The initial search yielded a total of 3148 titles. After the screening of titles and abstracts a total of 70 studies were selected for full-text review. Further full text reading and screening led to the exclusion of 51 studies (see details in supplementary Appendix 3 in the online Journal of Periodontology). Two more studies were further excluded because the same patient population was described, which resulted in the inclusion of a total of 19 studies reporting on single implants inserted immediately into a fresh extraction socket and provisionally restored in the maxillary aesthetic region (Table 1). ${ }^{19-37}$ Figure 1 outlines the search process. With the exception of one study, ${ }^{19}$ the other 18 studies were published during and after the year 2003. Most of the studies were prospective case series, the remainder were randomized controlled trials (RCT) and prospective cohort studies (Table 1).

\section{Patient and Site Characteristics}

The 19 included studies presenting data on a total of 485 patients with 472 implants placed into fresh extraction sockets and immediately restored in the maxillary aesthetic zone. Reasons for extraction included both periodontal and non-periodontal problems (caries, endodontic failure, root fracture, trauma, and root resorption). Details regarding the site and implant characteristics and measuring techniques for the included studies is outlined in Table 1.

\section{Soft Tissue Outcomes}

Most of the included studies quantified soft tissue alterations in terms of mid-facial gingival height and/or mesial papilla and distal papilla (Table 1). ${ }^{21-23,25-27,29-36}$ A variety of methods were used to measure this outcome, including standardized and non-standardized photographs, direct clinical measurements on the patient, and dental casts.

Mid-facial mucosa showed a mean overall recession of $0.27 \pm 0.38 \mathrm{~mm}$ after a follow-up period ranging from 1-5 years (Table 2). Most of these changes happened in the period between implant placement and definitive crown insertion. Within the $1^{\text {st }}$ year follow-up period after the definitive crown, a regrowth was seen leading to gain in soft tissue levels ($0.04 \pm 0.19 \mathrm{~mm})$. A few studies with follow-ups $>1$ year showed a very minimal loss of midfacial mucosa in the long term $(0.01 \pm 0.46 \mathrm{~mm}){ }^{24,25,27,29,36}$

In regards to papillary changes, a mean loss of $0.23 \pm 0.27 \mathrm{~mm}$ was seen (Table 2). Once again most of these changes happened before definitive crown placement. A papillary rebound was seen after the crown placement up to 1 year $(-0.13 \pm 0.18 \mathrm{~mm})$ and then from 1 year to the final follow-up in some studies $(-0.07 \pm 0.25 \mathrm{~mm}){ }^{25,27,29,36}$

\section{Variables Influencing Soft Tissue Changes}

The effect of various analyzed variables is presented in Table 3. The presence of a thin biotype was not seen to show any significant negative effect on the soft tissue changes following IPR technique. On the other hand, even though the use of a CTG with bone grafting at the time of implant placement was seen to limit the soft tissue recession it failed to have any statistically significant advantage on using a bone graft without a CTG. The limited number of studies which employed a surgical flap ${ }^{22,29}$ didn't show any significant difference in the amount of soft tissue changes as compared to studies which did not raise a flap. 


\section{Advanced Soft Tissue Changes (>1mm Recession)}

A total of seven studies provided data on advanced soft tissue recession of greater than $1 \mathrm{~mm}$ following implant placement with the IPR protocol. ${ }^{19,20,29,30,32-34}$ For the purpose of analysis, studies which included high risk cases ${ }^{20}$ or used a connective tissue graft during/after implant placement $^{30,33}$ were excluded from analysis. Amongst the four analyzed studies, ${ }^{19,29,32,34}$ midfacial advanced recession $\left(>1 \mathrm{~mm}\right.$ ) was reported as being less than $10 \%$ by two studies, ${ }^{29}$, ${ }^{32}$ with the other two studies ${ }^{19,} 34$ reporting an incidence between $10-20 \%$ (Table 4).

Notwithstanding the different protocols used, as well as the variable sample sizes and followup duration of the studies, a weighted mean was calculated to determine the percentage of cases showing advanced recession. The results showed a frequency of advanced mid-facial recession to be $11.02 \%$ across the four studies including 119 implants (Table 4).

\section{Aesthetic Outcomes}

Five of the 19 included studies provided information about the aesthetic outcomes of the treatment. $^{28,29,32,33,37}$ Aesthetic evaluation of the treatment outcome was carried out using the indices Pink Esthetic Score (PES) ${ }^{38}$ and/or White Esthetic Score (WES). ${ }^{39}$ All of the five studies quoted a mean PES score of $>10$, with no study reporting a mean WES score of $<8$ (Table 1). A PES score of less than 7 was used to define esthetic failure as proposed by Cosyn et al. ${ }^{29}$ Several studies were excluded for a variety of reasons including lack of details regarding aesthetic failures, ${ }^{37}$ inclusion of high risk cases (fractured facial plate), ${ }^{28}$ or the use of connective tissue grafting to manage recession. ${ }^{33}$ The mean aesthetic failure rate in the remaining two studies ${ }^{29,32}$ which included low risk cases was $11.2 \%$ (Table 4).

\section{Patient Reported Outcome Measures}

Only three of the included studies reported on patient satisfaction / patient centered outcome measures (Table 1). ${ }^{22,27,32}$ Kan et al. ${ }^{27}$ found that after a mean follow-up period of 2-8 years, only $11 \%$ of the patients were not satisfied with the esthetic outcome. Significant improvement in Oral Health Impact Profile -14 (OHIP-14) ${ }^{40}$ scores were reported by Raes et al. ${ }^{32}$ after a follow-up period of 1-year.

\section{DISCUSSION}

When assessing the adequacy of the soft tissue outcome in the context of aesthetics, there is general consensus that the papillae adjacent to the single-unit crown should mimic those of a healthy tooth, both in height and embrasure fill, and the mid-buccal gingival margin should harmonize with those of the adjacent teeth.

It has been proposed that the patient's gingival biotype impacts on the likelihood of achieving a successful aesthetic outcome. Indeed, a thick biotype was a prerequisite for patient inclusion in a few studies. ${ }^{22,32,33}$ However, the results from this review failed to find any significant advantage of a thick tissue biotype. It should be noted that the number of cases compared were limited and included studies had a considerable inherent heterogeneity. In relation to the issue of surgical access, the choice of whether a flap or flapless approach is employed did not appear to influence the final outcome. Therefore, it is still unclear whether the choice of utilizing a surgical flap or a flapless approach influences the final outcome, although a practical consideration is that the flapless approach is likely to make it easier to carry out the immediate restorative procedure.

In regards to bone augmentation procedures, 4 out of the 19 included studies did not use any material to graft the gap between the implant and socket. ${ }^{25,27,32,35}$ From the limited data available it was not possible to determine whether grafting between the implant and bone had 
any effect on the soft tissue levels around implants placed using the IPR protocol. The use of a CTG did not show any significant advantage in improving the soft tissue outcomes.

Although it has been used to manage advanced recession cases, ${ }^{33}$ this procedure has its own limitations with necrosis of the graft potentially leading to inferior aesthetic outcomes, ${ }^{30}$ and hence CTG can't be recommended as a routine procedure with the IPR technique.

The amount of mid-facial gingival recession after IPR technique was $0.27 \pm 0.38 \mathrm{~mm}$ after $\geq 1$ year of follow-up. These results are slightly better than the mid-facial recession of $0.54 \mathrm{~mm}$ ( $\geq 12$ months of follow-up) reported by another review on immediate placement in the aesthetic zone, ${ }^{14}$ with the slight difference in observed results due to the inclusion of both immediate and delayed restoration cases in the other review. It is noteworthy that various techniques like standardized and non-standardized photographs, direct clinical measurements on the patient, and dental casts were used in different studies which could have affected the results. It is difficult to standardize any specific method as it is a subjective measurement, but further research needs to be done to check the variability in results obtained with various techniques.

A weighted mean analysis of studies with low risk cases showed an advanced ( $>1 \mathrm{~mm})$ midfacial recession frequency of $11 \%$. Cosyn et al., ${ }^{18}$ in their systematic review on single immediate implants found an advanced recession frequency to be an infrequent finding. Out of four studies which provided data on advanced recession, they found only one to have a frequency of $>10 \%$. In the current review 5 studies provided data on advanced recession, ${ }^{19}$, $29,32-34$ of which two ${ }^{19,34}$ had a frequency of $>10 \%$. Therefore, if sensible patient selection criteria are followed, especially in relation to the integrity of the buccal socket wall, the incidence of advanced mid-facial recession $(>1 \mathrm{~mm})$ is relatively infrequent.

Mean papillary changes were limited to $0.23 \pm 0.27 \mathrm{~mm}$ recession after $\geq 1$ year of follow-up. These findings are similar to changes observed in another review. ${ }^{14}$ Interestingly, a gain in the level of interdental papillae was seen after definitive crown placement suggesting a papillary rebound. Studies with follow-ups longer than 1 year showed a tendency for the papillae to regrow improving the overall aesthetics. The finding of papillary rebound should be interpreted carefully as it is based on a limited number of heterogeneous studies. Nonetheless, it is an interesting finding which needs further research in the form of long term clinical trials.

Five studies used the PES and/or WES indices to evaluate the aesthetic outcome of immediately placed and restored implants. ${ }^{28,29,32,33,37}$ When considering the aesthetic outcomes according to the criteria described by Cosyn et al., ${ }^{29}$ the results from most of these studies suggest that an acceptable aesthetic outcome can be achieved when using the IPR treatment modality in the maxillary anterior region. An estimate of the frequency of unfavorable results/aesthetic failures (PES $<7$ ) showed $11 \%$ of cases falling below the threshold, but this finding was based on only two studies (Table 2). ${ }^{29,32}$

Patient assessment of the overall treatment procedure and results is a very important criterion, especially in relation to any restoration in the maxillary anterior region. However, patient reported outcome measures were reported by very few studies. ${ }^{22,27,32}$ The studies included in this review utilized various measures, including a Visual Analog Scale ${ }^{41}$ and the OHIP-14 index, ${ }^{40}$ for patient assessment of the treatment outcome. The results showed a significant improvement in the patient satisfaction after the replacement of an anterior tooth with the IPR technique. However, since only a very limited number of studies reported on patient centered parameters, this as an outcome measure that requires further investigation. 


\section{CONCLUSIONS}

Considerable heterogeneity was evident when comparing the different studies included in this review. Despite the relatively short time span (2003-2015) in which most of these studies were performed, the treatment procedures and materials have changed considerably leading to a large variance in the treatment protocols that were utilized.

Advanced mucosal recession was seen in $11 \%$ of low risk cases. The use of a flap or flapless technique did not appear to significantly influence the amount of soft tissue changes when utilizing the IPR protocol. Furthermore, although a thin gingival biotype has been considered as a risk factor for this technique, definite evidence could not be found to substantiate this. Similarly, a beneficial effect of the use of a CTG with bone graft could not be substantiated by the available evidence. More prospective, and ideally randomized clinical trials, are necessary to determine the effect of local and surgical factors on the soft tissue and aesthetic outcomes following immediate implant placement and restoration.

\section{ACKNOWLEDGEMENTS}

The authors have no conflict of interest in relation to this manuscript

\section{REFERENCES}

1. Adell R, Lekholm U, Rockler B, Branemark PI. A 15-year study of osseointegrated implants in the treatment of the edentulous jaw. Int J Oral Surg 1981;10:387-416.

2. Pjetursson BE, Tan K, Lang NP, Bragger U, Egger M, Zwahlen M. A systematic review of the survival and complication rates of fixed partial dentures (FPDs) after an observation period of at least 5 years. Clin Oral Implants Res 2004;15:625-642.

3. Pjetursson BE, Bragger U, Lang NP, Zwahlen M. Comparison of survival and complication rates of toothsupported fixed dental prostheses (FDPs) and implant-supported FDPs and single crowns (SCs). Clin Oral Implants Res 2007;18 Suppl 3:97-113.

4. Albrektsson T, Branemark PI, Hansson HA, Lindstrom J. Osseointegrated titanium implants. Requirements for ensuring a long-lasting, direct bone-to-implant anchorage in man. Acta Orthop Scand 1981;52:155-170.

5. Branemark PI, Adell R, Albrektsson T, Lekholm U, Lundkvist S, Rockler B. Osseointegrated titanium fixtures in the treatment of edentulousness. Biomaterials 1983;4:25-28.

6. De Rouck T, Collys K, Cosyn J. Immediate single-tooth implants in the anterior maxilla: a 1-year case cohort study on hard and soft tissue response. J Clin Periodontol 2008;35:649-657.

7. Kan JY, Rungcharassaeng K, Lozada J. Immediate placement and provisionalization of maxillary anterior single implants: 1-year prospective study. Int J Oral Maxillofac Implants 2003;18:31-39.

8. Atieh MA, Payne AG, Duncan WJ, Cullinan MP. Immediate restoration/loading of immediately placed single implants: is it an effective bimodal approach? Clin Oral Implants Res 2009;20:645-659.

9. Hammerle CH, Chen ST, Wilson TG, Jr. Consensus statements and recommended clinical procedures regarding the placement of implants in extraction sockets. Int J Oral Maxillofac Implants 2004;19 Suppl:26-28.

10. Cochran DL. The evidence for immediate loading of implants. J Evid Based Dent Pract 2006;6:155-163.

11. De Rouck T, Collys K, Cosyn J. Single-tooth replacement in the anterior maxilla by means of immediate implantation and provisionalization: a review. Int J Oral Maxillofac Implants 2008;23:897-904.

12. den Hartog L, Slater JJ, Vissink A, Meijer HJ, Raghoebar GM. Treatment outcome of immediate, early and conventional single-tooth implants in the aesthetic zone: a systematic review to survival, bone level, softtissue, aesthetics and patient satisfaction. J Clin Periodontol 2008;35:1073-1086.

13. Esposito M, Grusovin MG, Polyzos IP, Felice P, Worthington HV. Interventions for replacing missing teeth: dental implants in fresh extraction sockets (immediate, immediate-delayed and delayed implants). The Cochrane database of systematic reviews 2010:CD005968. 
14. Slagter KW, den Hartog L, Bakker NA, Vissink A, Meijer HJ, Raghoebar GM. Immediate placement of dental implants in the esthetic zone: a systematic review and pooled analysis. J Periodontol 2014;85:e241250.

15. Moher D, Liberati A, Tetzlaff J, Altman DG, Group P. Preferred reporting items for systematic reviews and meta-analyses: the PRISMA statement. PLoS Med 2009;6:e1000097.

16. Needleman I. Introduction to evidence-based dentistry. In: Clarkson J HJ, Ismail AI, Needleman I, Worthington HV ed. Evidence based dentistry for effective practice. London: Taylor and Francis, 2002:118.

17. Higgins JP, Altman DG, Gotzsche PC, et al. The Cochrane Collaboration's tool for assessing risk of bias in randomised trials. BMJ 2011;343:d5928.

18. Cosyn J, Hooghe N, De Bruyn H. A systematic review on the frequency of advanced recession following single immediate implant treatment. J Clin Periodontol 2012;39:582-589.

19. Wohrle PS. Single-tooth replacement in the aesthetic zone with immediate provisionalization: fourteen consecutive case reports. Pract Periodontics Aesthet Dent 1998;10:1107-1114; quiz 1116.

20. Kan JY, Rungcharassaeng K, Sclar A, Lozada JL. Effects of the facial osseous defect morphology on gingival dynamics after immediate tooth replacement and guided bone regeneration: 1-year results. $J$ Oral Maxillofac Surg 2007;65:13-19.

21. Canullo L, Rasperini G. Preservation of Peri-implant Soft and Hard Tissues Using Platform Switching of Implants Placed in Immediate Extraction Sockets: A Proof-of-Concept Study with 12- to 36-month Followup. Int J Oral Maxillofac Implants 2007;22:995-1000.

22. De Rouck T, Collys K, Wyn I, Cosyn J. Instant provisionalization of immediate single-tooth implants is essential to optimize esthetic treatment outcome. Clin Oral Implants Res 2009;20:566-570.

23. Kan JY, Rungcharassaeng K, Morimoto T, Lozada J. Facial gingival tissue stability after connective tissue graft with single immediate tooth replacement in the esthetic zone: consecutive case report. J Oral Maxillofac Surg 2009;67:40-48.

24. Block MS, Mercante DE, Lirette D, Mohamed W, Ryser M, Castellon P. Prospective evaluation of immediate and delayed provisional single tooth restorations. J Oral Maxillofac Surg 2009;67:89-107.

25. Tortamano P, Camargo LO, Bello-Silva MS, Kanashiro LH. Immediate implant placement and restoration in the esthetic zone: a prospective study with 18 months of follow-up. Int J Oral Maxillofac Implants 2010;25:345-350.

26. Pieri F, Aldini NN, Marchetti C, Corinaldesi G. Influence of implant-abutment interface design on bone and soft tissue levels around immediately placed and restored single-tooth implants: a randomized controlled clinical trial. Int J Oral Maxillofac Implants 2011;26:169-178.

27. Kan JY, Rungcharassaeng K, Lozada JL, Zimmerman G. Facial gingival tissue stability following immediate placement and provisionalization of maxillary anterior single implants: a 2- to 8-year follow-up. Int J Oral Maxillofac Implants 2011;26:179-187.

28. Noelken R, Kunkel M, Wagner W. Immediate implant placement and provisionalization after long-axis root fracture and complete loss of the facial bony lamella. Int J Periodontics Restorative Dent 2011;31:175-183.

29. Cosyn J, Eghbali A, De Bruyn H, Collys K, Cleymaet R, De Rouck T. Immediate single-tooth implants in the anterior maxilla: 3-year results of a case series on hard and soft tissue response and aesthetics. J Clin Periodontol 2011;38:746-753.

30. Tsuda H, Rungcharassaeng K, Kan JY, Roe P, Lozada JL, Zimmerman G. Peri-implant tissue response following connective tissue and bone grafting in conjunction with immediate single-tooth replacement in the esthetic zone: a case series. Int J Oral Maxillofac Implants 2011;26:427-436.

31. Brown SD, Payne AG. Immediately restored single implants in the aesthetic zone of the maxilla using a novel design: 1-year report. Clin Oral Implants Res 2011;22:445-454.

32. Raes F, Cosyn J, De Bruyn H. Clinical, aesthetic, and patient-related outcome of immediately loaded single implants in the anterior maxilla: a prospective study in extraction sockets, healed ridges, and grafted sites. Clin Implant Dent Relat Res 2013;15:819-835. 
33. Cosyn J, De Bruyn H, Cleymaet R. Soft tissue preservation and pink aesthetics around single immediate implant restorations: a 1-year prospective study. Clin Implant Dent Relat Res 2013;15:847-857.

34. Malchiodi L, Cucchi A, Ghensi P, Nocini PF. Evaluation of the esthetic results of 64 nonfunctional immediately loaded postextraction implants in the maxilla: correlation between interproximal alveolar crest and soft tissues at 3 years of follow-up. Clin Implant Dent Relat Res 2013;15:130-142.

35. Cabello G, Rioboo M, Fabrega JG. Immediate placement and restoration of implants in the aesthetic zone with a trimodal approach: soft tissue alterations and its relation to gingival biotype. Clin Oral Implants Res 2013;24:1094-1100.

36. Cooper LF, Reside GJ, Raes F, et al. Immediate provisionalization of dental implants placed in healed alveolar ridges and extraction sockets: a 5-year prospective evaluation. Int J Oral Maxillofac Implants 2014;29:709-717.

37. Cardaropoli D, Tamagnone L, Roffredo A, Gaveglio L. Soft tissue contour changes at immediate postextraction single-tooth implants with immediate restoration: a 12-month prospective cohort study. Int $J$ Periodontics Restorative Dent 2015;35:191-198.

38. Furhauser R, Florescu D, Benesch T, Haas R, Mailath G, Watzek G. Evaluation of soft tissue around singletooth implant crowns: the pink esthetic score. Clin Oral Implants Res 2005;16:639-644.

39. Belser UC, Grutter L, Vailati F, Bornstein MM, Weber HP, Buser D. Outcome evaluation of early placed maxillary anterior single-tooth implants using objective esthetic criteria: a cross-sectional, retrospective study in 45 patients with a 2- to 4-year follow-up using pink and white esthetic scores. J Periodontol 2009;80:140-151.

40. Slade GD. Derivation and validation of a short-form oral health impact profile. Community Dent Oral Epidemiol 1997;25:284-290.

41. McCormack HM, Horne DJ, Sheather S. Clinical applications of visual analogue scales: a critical review. Psychol Med 1988;18:1007-1019.

Correspondence: Prof. Saso Ivanovski, School of Dentistry and Oral Health, Griffith Health Centre, Griffith University -Gold Coast Campus, Parklands Drive, QLD 4222, Australia, Tel: +61 7 56780741, Fax: +61 75678 0708, Email: s.ivanovski@griffith.edu.au

Submitted May 3, 2015; accepted for publication July 31, 2015.

\section{Figure 1.}

Flowchart of study selection process according to the PRISMA statement 
Table 1.

Studies using the IPR protocol and their parameters

\begin{tabular}{|c|c|c|c|c|c|c|c|c|c|c|c|c|c|c|c|}
\hline Authors & \begin{tabular}{|l|} 
Study \\
Design \\
(Groups \\
)
\end{tabular} & $\begin{array}{l}\text { Risk } \\
\text { of } \\
\text { bias }\end{array}$ & $\begin{array}{l}\text { Impla } \\
\text { nt } \\
\text { System }\end{array}$ & $\begin{array}{l}\text { Follow- } \\
\text { up(mon } \\
\text { ths) }\end{array}$ & $\begin{array}{l}\text { No of } \\
\text { impla } \\
\text { nts/ } \\
\text { No of } \\
\text { patien } \\
\text { ts }\end{array}$ & $\begin{array}{l}\text { Implant } \\
\text { position } \\
\text { (Corono- } \\
\text { apical) }\end{array}$ & $\begin{array}{l}\text { Gingival } \\
\text { Biotype }\end{array}$ & $\begin{array}{l}\text { Flap/Fla } \\
\text { pless }\end{array}$ & $\begin{array}{l}\text { Graft } \\
\text { used }\end{array}$ & $\begin{array}{c}\text { Measuri } \\
\text { ng } \\
\text { techniqu } \\
\text { e }\end{array}$ & $\begin{array}{c}\text { Mid- } \\
\text { facial } \\
\text { recess } \\
\text { ion }\end{array}$ & $\begin{array}{c}\text { Interpro } \\
\text { ximal } \\
\text { recession }\end{array}$ & $\begin{array}{c}\text { Papil } \\
\text { la } \\
\text { Inde } \\
\text { x }\end{array}$ & $\begin{array}{l}\text { PES/ } \\
\text { WES }\end{array}$ & $\begin{array}{c}\text { Patient } \\
\text { s } \\
\text { aestheti } \\
\text { c } \\
\text { evaluat } \\
\text { on }\end{array}$ \\
\hline $\begin{array}{l}\text { Wöhrle } \\
{(1998)^{19}}^{19}\end{array}$ & CS & High & $\begin{array}{l}\text { Steri- } \\
\text { Oss }\end{array}$ & $9-36$ & $14 / 14$ & $\begin{array}{l}\text { 3mm } \\
\text { apical to } \\
\text { the labial } \\
\text { gingival } \\
\text { margin }\end{array}$ & 1 & Flapless & $\begin{array}{l}\text { Autogen } \\
\text { ous } \\
\text { (few } \\
\text { cases) }\end{array}$ & $\begin{array}{c}\text { Photogra } \\
\text { phs }\end{array}$ & $\begin{array}{c}14.3 \% \\
\text { showe } \\
\mathrm{d}>1 \\
\mathrm{~mm} \\
\text { recess } \\
\text { ion }\end{array}$ & 1 & 1 & 1 & 1 \\
\hline \multirow{2}{*}{$\begin{array}{l}\text { Kan et } \\
\text { al. } \\
(2007 b)^{20}\end{array}$} & \multirow[t]{2}{*}{ CS } & \multirow[t]{2}{*}{$\begin{array}{l}\text { Medi } \\
\text { um }\end{array}$} & \multirow[t]{2}{*}{$\begin{array}{l}\text { Nobel } \\
\text { Biocare }\end{array}$} & \multirow[t]{2}{*}{12} & \multirow[t]{2}{*}{$23 / 23$} & \multirow{2}{*}{$\begin{array}{l}\text { 3mm } \\
\text { from the } \\
\text { predeter } \\
\text { mined } \\
\text { gingival } \\
\text { margin }\end{array}$} & $\begin{array}{l}\text { Thick- } \\
10\end{array}$ & \multirow{2}{*}{$\begin{array}{l}15 \text { Flap; } \\
8 \\
\text { Flapless }\end{array}$} & \multirow{2}{*}{$\begin{array}{l}\text { Autogen } \\
\text { ous/ } \\
\text { Xenogra } \\
\mathrm{ft}+ \\
\text { Membra } \\
\text { ne } \\
\text { (SCTG } \\
\text { 11/23) }\end{array}$} & \multirow{2}{*}{$\begin{array}{c}\text { Digital } \\
\text { photogra } \\
\text { phs and } \\
\text { study } \\
\text { casts }\end{array}$} & \multirow{2}{*}{$\begin{array}{c}34.8 \% \\
\text { showe } \\
\mathrm{d}>1.5 \\
\mathrm{~mm} \\
\text { recess } \\
\text { ion }\end{array}$} & \multirow[t]{2}{*}{1} & \multirow[t]{2}{*}{1} & \multirow[t]{2}{*}{1} & \multirow[t]{2}{*}{1} \\
\hline & & & & & & & Thin- 13 & & & & & & & & \\
\hline \multirow{2}{*}{$\begin{array}{l}\text { Canullo } \\
\& \\
\text { Rasperin } \\
\text { i }(2007)^{21}\end{array}$} & \multirow[t]{2}{*}{$\mathrm{CS}$} & \multirow[t]{2}{*}{$\begin{array}{l}\text { Medi } \\
\text { um }\end{array}$} & \multirow[t]{2}{*}{ Defcon } & \multirow[t]{2}{*}{$\begin{array}{l}22(18- \\
36)\end{array}$} & \multirow[t]{2}{*}{$10 / 9$} & \multirow[t]{2}{*}{$\begin{array}{l}\text { Level } \\
\text { of bony } \\
\text { wall }\end{array}$} & Thick -8 & \multirow[t]{2}{*}{$\begin{array}{l}\text { Flaples } \\
\text { s }\end{array}$} & \multirow[t]{2}{*}{$\begin{array}{l}\text { Xenog } \\
\text { raft }+ \\
\text { blood }\end{array}$} & \multirow[t]{2}{*}{$\begin{array}{l}\text { Digital } \\
\text { photogr } \\
\text { aphs }\end{array}$} & \multirow[t]{2}{*}{$\begin{array}{l}-0.2 \\
\mathrm{~mm}\end{array}$} & $\begin{array}{l}\mathrm{M}:- \\
0.40 \\
\mathrm{~mm}\end{array}$ & \multirow[t]{2}{*}{ / } & \multirow[t]{2}{*}{1} & \multirow[t]{2}{*}{1} \\
\hline & & & & & & & Thin - 2 & & & & & $\begin{array}{c}\text { D: }-0.10 \\
\text { mm }\end{array}$ & & & \\
\hline \multirow{2}{*}{$\begin{array}{l}\text { De } \\
\text { Rouck et } \\
\text { al. (2009) } \\
22\end{array}$} & \multirow[t]{2}{*}{$\begin{array}{l}\text { RCT (IR } \\
\text { vs. DR) }\end{array}$} & \multirow[t]{2}{*}{ Low } & \multirow[t]{2}{*}{$\begin{array}{l}\text { Nobel } \\
\text { Biocare }\end{array}$} & \multirow[t]{2}{*}{12} & \multirow[t]{2}{*}{$\begin{array}{l}24 / 24 \\
\text { IPR }\end{array}$} & \multirow{2}{*}{$\begin{array}{l}1 \mathrm{~mm} \\
\text { subcresta } \\
\text { lly or } \\
4 \mathrm{~mm} \\
\text { below } \\
\text { the peri- } \\
\text { implant } \\
\text { mucosa }\end{array}$} & \multirow[t]{2}{*}{$\begin{array}{l}\text { Normal - } \\
\text { Thick }\end{array}$} & Flap & $\begin{array}{l}\text { Xenogra } \\
\mathrm{ft}\end{array}$ & $\begin{array}{c}\text { Clinicall } \\
\mathrm{y}\end{array}$ & $\begin{array}{c}0.41 \\
\mathrm{~mm}\end{array}$ & $\begin{array}{c}\text { M: } 0.44 \\
\text { mm }\end{array}$ & 1 & 1 & $\begin{array}{c}\text { Mean } \\
93 / 100\end{array}$ \\
\hline & & & & & & & & & & & & $\begin{array}{c}\mathrm{D}: 0.31 \\
\mathrm{~mm}\end{array}$ & & & \\
\hline $\begin{array}{l}\text { Kan et } \\
\text { al. }\end{array}$ & $\mathrm{Ct}$ & Low & $\begin{array}{l}\text { Nobel } \\
\text { Biocare }\end{array}$ & 25.8 & $20 / 20$ & $\begin{array}{l}3 \mathrm{~mm} \\
\text { from the }\end{array}$ & $\begin{array}{l}\text { Thick/Th } \\
\text { in }\end{array}$ & Flapless & $\begin{array}{l}\text { Xenogra } \\
\mathrm{ft}+\end{array}$ & $\begin{array}{c}\text { Study } \\
\text { casts }\end{array}$ & $\begin{array}{l}\text { Overa } \\
\text { ll: - }\end{array}$ & 1 & NS & 1 & 1 \\
\hline
\end{tabular}




\begin{tabular}{|c|c|c|c|c|c|c|c|c|c|c|c|c|c|c|c|}
\hline$(2009)^{23}$ & & & & & & $\begin{array}{l}\text { predeter } \\
\text { mined } \\
\text { gingival } \\
\text { margin }\end{array}$ & & & SCTG & & $\begin{array}{l}0.13 \\
\mathrm{~mm}\end{array}$ & & & & \\
\hline $\begin{array}{l}\text { Block et } \\
\text { al. (2009) } \\
24\end{array}$ & $\begin{array}{l}\text { RCT (IP } \\
\text { vs. DP) }\end{array}$ & High & $\begin{array}{l}\text { Biomet } \\
3 \mathrm{i}\end{array}$ & $18-24$ & $\begin{array}{l}26 / 26 \\
\text { IPR }\end{array}$ & $\begin{array}{l}\text { 3mm } \\
\text { apical to } \\
\text { the future } \\
\text { gingival } \\
\text { margin }\end{array}$ & 1 & $\begin{array}{l}\text { Flap/Flap } \\
\text { less }\end{array}$ & $\begin{array}{l}\text { Human } \\
\text { minerali } \\
\text { zed } \\
\text { bone }\end{array}$ & $\begin{array}{c}\text { Clinicall } \\
\mathrm{y}\end{array}$ & $\begin{array}{l}0.41 \\
\mathrm{~mm}\end{array}$ & I & 1 & 1 & 1 \\
\hline $\begin{array}{l}\text { Tortama } \\
\text { no et al. } \\
(2010)^{25}\end{array}$ & $\mathrm{CS}$ & $\begin{array}{l}\text { Medi } \\
\text { um }\end{array}$ & $\begin{array}{l}\text { Straum } \\
\text { ann }\end{array}$ & 18 & $12 / 12$ & $\begin{array}{l}2 \mathrm{~mm} \\
\text { apical to } \\
\text { the future } \\
\text { gingival } \\
\text { margin }\end{array}$ & I & Flapless & None & $\begin{array}{l}\text { Study } \\
\text { Casts }\end{array}$ & $\begin{array}{c}-0.03 \\
\mathrm{~mm}\end{array}$ & $\begin{array}{c}\text { M: }-0.14 \\
\text { mm }\end{array}$ & I & I & I \\
\hline $\begin{array}{l}\text { Pieri et } \\
\text { al. } \\
(2011)^{26}\end{array}$ & $\begin{array}{l}\text { RCT } \\
\text { (Morse } \\
\text { taper vs. } \\
\text { conventi } \\
\text { onal) } \\
\end{array}$ & Low & $\begin{array}{l}\text { Biospa } \\
\text { rk }\end{array}$ & 12 & $40 / 40$ & $\begin{array}{l}0.5 \mathrm{~mm} \\
\text { coronal } \\
\text { to } \\
\text { alveolar } \\
\text { crest } \\
\end{array}$ & I & Flapless & $\begin{array}{l}\text { Autogen } \\
\text { ous } \\
+ \text { Xeno } \\
\text { graft }\end{array}$ & $\begin{array}{c}\text { Study } \\
\text { cast } \\
\text { photogra } \\
\text { phed }\end{array}$ & $\begin{array}{l}0.61 \\
\mathrm{~mm}\end{array}$ & $\begin{array}{c}\mathrm{M}: 0.24 \\
\mathrm{~mm}\end{array}$ & I & I & / \\
\hline $\begin{array}{l}\text { Kan et } \\
\text { al. } \\
(2011)^{27}\end{array}$ & PS & $\begin{array}{l}\text { Medi } \\
\text { um }\end{array}$ & $\begin{array}{l}\text { Nobel } \\
\text { Biocare }\end{array}$ & $24-96$ & $35 / 35$ & 1 & $\begin{array}{l}\text { Thick/Th } \\
\text { in }\end{array}$ & Flapless & None & $\begin{array}{c}\text { Digital } \\
\text { photogra } \\
\text { phs }\end{array}$ & $\begin{array}{l}1.13 \\
\mathrm{~mm}\end{array}$ & $\begin{array}{c}\mathrm{M}: 0.22 \\
\mathrm{~mm}\end{array}$ & I & 1 & $\begin{array}{c}11 \% \\
\text { unsatisf } \\
\text { ed }\end{array}$ \\
\hline $\begin{array}{l}\text { Noelken } \\
\text { et } \\
\text { al. (2011) } \\
28\end{array}$ & PS & High & $\begin{array}{l}\text { Nobel } \\
\text { Biocare }\end{array}$ & $13-36$ & $18 / 16$ & $\begin{array}{l}2 \mathrm{~mm} \\
\text { apical to } \\
\text { soft } \\
\text { tissue } \\
\text { margin } \\
\end{array}$ & 1 & Flapless & $\begin{array}{l}\text { Autogen } \\
\text { ous } \\
\text { bone } \\
\text { chips }\end{array}$ & $\begin{array}{c}\text { Digital } \\
\text { photogra } \\
\text { phs }\end{array}$ & I & I & I & $\begin{array}{l}\text { Mean } \\
12.5 /-\end{array}$ & I \\
\hline $\begin{array}{l}\text { Cosyn et } \\
\text { al. } \\
(2011)^{29}\end{array}$ & CS & Low & $\begin{array}{l}\text { Nobel } \\
\text { Biocare }\end{array}$ & 36 & $25 / 25$ & $\begin{array}{l}1 \mathrm{~mm} \\
\text { subcresta } \\
\text { lly or } \\
4 \mathrm{~mm} \\
\text { below } \\
\text { the peri- } \\
\text { implant } \\
\text { mucosa } \\
\end{array}$ & Thick & Flap & $\begin{array}{l}\text { Xenogra } \\
\mathrm{ft}+ \\
\text { blood }\end{array}$ & $\begin{array}{c}\text { Clinicall } \\
\mathrm{y}\end{array}$ & $\begin{array}{l}0.34 \\
\mathrm{~mm}\end{array}$ & $\begin{array}{c}\mathrm{M}: 0.05 \\
\mathrm{~mm}\end{array}$ & I & $\begin{array}{c}\text { Mean } \\
10.48 / \\
8.17\end{array}$ & I \\
\hline $\begin{array}{l}\text { Tsuda et } \\
\text { al. }\end{array}$ & CS & High & $\begin{array}{l}\text { Astra } \\
\text { Tech }\end{array}$ & 12 & $10 / 10$ & $\begin{array}{l}3 \mathrm{~mm} \\
\text { apical to }\end{array}$ & I & Flapless & $\begin{array}{l}\text { Xenogra } \\
\mathrm{ft}+\end{array}$ & $\begin{array}{c}\text { Clinicall } \\
\mathrm{y} \\
\end{array}$ & $\begin{array}{l}0.05 \\
\mathrm{~mm}\end{array}$ & I & NS & I & / \\
\hline
\end{tabular}




\begin{tabular}{|c|c|c|c|c|c|c|c|c|c|c|c|c|c|c|c|}
\hline$(2011)^{30}$ & & & & & & $\begin{array}{l}\text { the future } \\
\text { gingival } \\
\text { margin }\end{array}$ & & & SCTG & & & & & & \\
\hline $\begin{array}{l}\text { Brown } \\
\text { and } \\
\text { Payne } \\
(2011)^{31}\end{array}$ & $\mathrm{CS}$ & High & $\begin{array}{l}\text { Southe } \\
\text { rn } \\
\text { Implan } \\
\text { ts }\end{array}$ & 12 & $28 / 27$ & $\begin{array}{l}\text { 3mm } \\
\text { apical to } \\
\text { mid- } \\
\text { buccal } \\
\text { mucosal } \\
\text { level }\end{array}$ & 1 & Flapless & / & $\begin{array}{c}\text { Digital } \\
\text { photogra } \\
\text { phs }\end{array}$ & $\begin{array}{l}-0.2 \\
\mathrm{~mm}\end{array}$ & I & $\begin{array}{l}\text { Grad } \\
\text { ual } \\
\text { incre } \\
\text { ase } \\
\text { in } \\
\text { papil } \\
\text { la fill } \\
\end{array}$ & I & I \\
\hline \multirow{2}{*}{$\begin{array}{l}\text { Raes et } \\
\text { al. } \\
(2013)^{32}\end{array}$} & \multirow[t]{2}{*}{$\begin{array}{l}\text { PS (IP } \\
\text { vs. DP) }\end{array}$} & \multirow[t]{2}{*}{ Low } & \multirow[t]{2}{*}{$\begin{array}{l}\text { Astra } \\
\text { Tech }\end{array}$} & \multirow[t]{2}{*}{12} & \multirow[t]{2}{*}{$\begin{array}{l}16 / 16 \\
\text { IPR }\end{array}$} & \multirow{2}{*}{$\begin{array}{l}\text { At the } \\
\text { level of } \\
\text { crest of } \\
\text { buccal } \\
\text { bone }\end{array}$} & \multirow[t]{2}{*}{ Thick } & \multirow[t]{2}{*}{$\begin{array}{l}\text { Flap/Flap } \\
\text { less }\end{array}$} & \multirow[t]{2}{*}{ None } & \multirow{2}{*}{$\begin{array}{l}\text { Photos, } \\
\text { stand } \\
\text { with bite } \\
\text { fork and } \\
\quad \text { jig }\end{array}$} & \multirow[t]{2}{*}{$\begin{array}{l}0.12 \\
\mathrm{~mm}\end{array}$} & $\begin{array}{c}\text { M: }-0.07 \\
\text { mm }\end{array}$ & \multirow[t]{2}{*}{1} & \multirow{2}{*}{$\begin{array}{c}\text { Mean } \\
10.33 / \\
7.11\end{array}$} & \multirow{2}{*}{$\begin{array}{c}\text { Significa } \\
\text { nt } \\
\text { improve } \\
\text { ment in } \\
\text { OHIP- } \\
14 \\
\text { scores }\end{array}$} \\
\hline & & & & & & & & & & & & $\begin{array}{c}\mathrm{D}: 0.38 \\
\mathrm{~mm}\end{array}$ & & & \\
\hline \multirow{2}{*}{$\begin{array}{l}\text { Cosyn et } \\
\text { al. } \\
(2013 a)^{3}\end{array}$} & \multirow[t]{2}{*}{$\mathrm{CS}$} & \multirow[t]{2}{*}{ Low } & \multirow[t]{2}{*}{$\begin{array}{l}\text { Nobel } \\
\text { Biocare }\end{array}$} & \multirow[t]{2}{*}{12} & \multirow[t]{2}{*}{$22 / 22$} & \multirow{2}{*}{$\begin{array}{l}2 \mathrm{~mm} \\
\text { apical to } \\
\text { the } \\
\text { midfacial } \\
\text { gingival } \\
\text { margin } \\
\end{array}$} & \multirow[t]{2}{*}{ Thick } & \multirow[t]{2}{*}{ Flapless } & \multirow{2}{*}{$\begin{array}{l}\text { Xenogra } \\
\mathrm{ft}+ \\
\text { blood (7 } \\
\text { cases } \\
\text { SCTG) }\end{array}$} & \multirow[t]{2}{*}{$\begin{array}{c}\text { Clinicall } \\
\mathrm{y}\end{array}$} & \multirow[t]{2}{*}{$\begin{array}{r}0.2 \\
\mathrm{~mm}\end{array}$} & $\begin{array}{c}\text { M: } 0.20 \\
\text { mm }\end{array}$ & \multirow[t]{2}{*}{ I } & \multirow{2}{*}{$\begin{array}{c}\text { Mean } \\
12.15 / \\
8.63\end{array}$} & \multirow[t]{2}{*}{ I } \\
\hline & & & & & & & & & & & & $\begin{array}{c}\mathrm{D}: 0.50 \\
\mathrm{~mm}\end{array}$ & & & \\
\hline \multirow{2}{*}{$\begin{array}{l}\text { Malchio } \\
\text { di et al. } \\
(2013)^{34}\end{array}$} & \multirow[t]{2}{*}{ PS } & \multirow[t]{2}{*}{$\begin{array}{l}\text { Medi } \\
\text { um }\end{array}$} & \multirow{2}{*}{$\begin{array}{l}\text { FBR } \\
\text { coated } \\
\text { implant } \\
\text { s }\end{array}$} & \multirow[t]{2}{*}{36} & $64 / 58$ & $\begin{array}{l}\text { At the } \\
\text { level of }\end{array}$ & $\begin{array}{l}\text { Thick/No } \\
\text { rmal }\end{array}$ & Flapless & $\begin{array}{l}\text { Autogen } \\
\text { ous }\end{array}$ & $\begin{array}{c}\text { Digital } \\
\text { photogra }\end{array}$ & $\begin{array}{r}0.5 \\
\mathrm{~mm}\end{array}$ & $\begin{array}{c}\text { M: } 0.6 \\
\text { mm }\end{array}$ & 1 & 1 & 1 \\
\hline & & & & & & $\begin{array}{l}\text { alveolar } \\
\text { crest }\end{array}$ & & & $\begin{array}{l}\text { bone } \\
\text { chips (if } \\
\text { needed) }\end{array}$ & phs & & $\begin{array}{c}\text { D: } 0.8 \\
\mathrm{~mm}\end{array}$ & & & \\
\hline $\begin{array}{l}\text { Cabello } \\
\text { et al. }\end{array}$ & PS & High & $\begin{array}{l}\text { Straum } \\
\text { ann }\end{array}$ & 12 & $14 / 14$ & $\begin{array}{l}2 \mathrm{~mm} \text { or } \\
3 \mathrm{~mm}\end{array}$ & 1 & Flapless & None & $\begin{array}{c}\text { Clinicall } \\
\mathrm{y}\end{array}$ & $\begin{array}{l}0.45 \\
\mathrm{~mm}\end{array}$ & $\begin{array}{c}\text { M: } 0.38 \\
\text { mm }\end{array}$ & 1 & 1 & 1 \\
\hline$(2013)^{35}$ & & & & & & $\begin{array}{l}\text { apical to } \\
\text { bone }\end{array}$ & & & & & & $\begin{array}{c}\mathrm{D}: 0.80 \\
\mathrm{~mm}\end{array}$ & & & \\
\hline $\begin{array}{l}\text { Cooper } \\
\text { et } \\
\text { al. (2014) } \\
36\end{array}$ & $\begin{array}{l}\text { PS (IP } \\
\text { VS. DP) }\end{array}$ & High & $\begin{array}{l}\text { Astra } \\
\text { Tech }\end{array}$ & 60 & $\begin{array}{l}58 / 55 \\
\text { IPR }\end{array}$ & $\begin{array}{l}\text { At the } \\
\text { level of } \\
\text { facial } \\
\text { osseous } \\
\text { crest }\end{array}$ & 1 & Flapless & 1 & $\begin{array}{c}\text { Clinicall } \\
\mathrm{y}\end{array}$ & $\begin{array}{c}-0.23 \\
\mathrm{~mm}\end{array}$ & $\begin{array}{c}\text { Mean } \\
\text { papilla } \\
0.29 \mathrm{~mm} \\
\text { gain }\end{array}$ & 1 & 1 & 1 \\
\hline Cardaro & PS & High & T3, & 12 & $26 / 26$ & 1 & 1 & Flapless & Xenogra & Clinicall & 0.21 & $0.17 \mathrm{~mm}$ & 0.08 & Mean & 1 \\
\hline
\end{tabular}




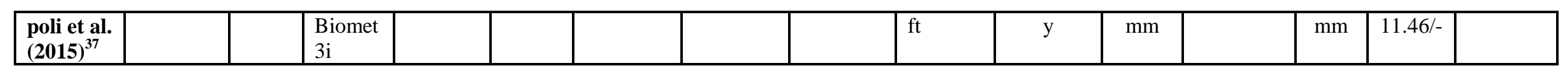

(Ct: cohort study; D: distal papilla; DP: delayed placement; DR: delayed restoration; IL: immediate loading; IP: immediate placement; IR: immediate restoration; M: mesial papilla; SCTG: connective tissue graft; /: not reported; negative values show gain in soft tissue level)

Table 2.

Soft tissue changes at various time-points

\begin{tabular}{|c|c|c|c|c|c|c|c|c|c|}
\hline \multirow[t]{2}{*}{ Study } & \multirow[t]{2}{*}{$\mathbf{N}$} & \multicolumn{2}{|c|}{$\mathbf{B L}-\mathbf{F L}$} & \multicolumn{2}{|c|}{ BL - DC } & \multicolumn{2}{|c|}{ DC - 1 year } & \multicolumn{2}{|c|}{1 year - FL } \\
\hline & & $\mathrm{MF}$ & Papilla & MF & Papilla & MF & Papilla & MF & Papilla \\
\hline Canullo \& Rasperini (2007) & 10 & -0.2 & -0.25 & 1 & 1 & 1 & 1 & 1 & 1 \\
\hline De Rouck et al. (2009) & 24 & 0.41 & 0.38 & 0.47 & 0.38 & -0.06 & 0.0 & 1 & 1 \\
\hline Kan et al. (2009) ${ }^{23}$ & 20 & -0.13 & 1 & 1 & 1 & 1 & 1 & 1 & 1 \\
\hline Block et al. (2009) $)^{24}$ & 26 & 1 & / & 1 & 1 & 0.24 & 1 & -0.65 & 1 \\
\hline Tortamano et al. (2010) ${ }^{25}$ & 12 & 1 & -0.09 & 1 & 0.06 & -0.06 & -0.15 & 0.03 & -0.01 \\
\hline Pieri et al. $(2011)^{26}$ & 40 & 0.67 & 0.3 & 0.58 & 0.32 & 0.12 & -0.02 & 1 & 1 \\
\hline Kan et al. (2011) & 35 & 1.13 & 0.22 & 0.48 & 0.44 & 0.07 & 0.02 & 0.58 & -0.26 \\
\hline Cosyn et al. (2011) & 25 & 0.34 & 0.07 & 0.54 & 0.36 & -0.01 & -0.1 & -0.19 & -0.30 \\
\hline Tsuda et al. (2011) & 10 & 0.05 & 1 & 0.0 & 1 & 0.05 & 1 & 1 & 1 \\
\hline Brown and Payne (2011) & 28 & -0.2 & 1 & -0.2 & 1 & 0.0 & 1 & 1 & 1 \\
\hline Raes et al. (2013) & 16 & 0.12 & 0.16 & 0.35 & 0.64 & -0.23 & -0.48 & 1 & 1 \\
\hline Cosyn et al. (2013a) ${ }^{33}$ & 22 & 0.2 & 0.4 & 0.3 & 0.4 & 0.1 & 0.0 & 1 & 1 \\
\hline Malchiodi et al. (2013) & 64 & 0.5 & 0.7 & 1 & 1 & 1 & 1 & 1 & 1 \\
\hline Cabello et al. (2013) ${ }^{35}$ & 14 & 0.45 & 0.59 & 1 & 1 & 1 & 1 & 1 & 1 \\
\hline Cooper et al. (2014) $^{36}$ & 58 & 1 & 0.17 & 1 & 0.26 & -0.35 & -0.35 & 0.29 & 0.26 \\
\hline Cardaropoli et al. (2015) ${ }^{37}$ & 26 & 0.21 & 0.13 & 1 & 1 & 1 & 1 & I & 1 \\
\hline Mean & & 0.27 & 0.23 & 0.32 & 0.36 & -0.04 & -0.13 & 0.01 & -0.07 \\
\hline SD & & 0.38 & 0.27 & 0.28 & 0.16 & 0.19 & 0.18 & 0.46 & 0.25 \\
\hline Weighted Mean & & 0.37 & 0.30 & 0.39 & 0.34 & -0.06 & -0.13 & 0.10 & -0.01 \\
\hline
\end{tabular}

BL: baseline; DC: definitive crown; FL: final follow-up; MF: midfacial mucosa; N: number of implants; negative values show gain in soft tissue 
Table 3.

Variables influencing soft tissue changes

\begin{tabular}{|c|c|c|c|c|c|c|}
\hline & $\begin{array}{l}\text { Number of } \\
\text { implants }\end{array}$ & $\begin{array}{c}\text { Mean Midfacial } \\
\text { mucosal changes in } \\
\text { mm(SD) }\end{array}$ & $P$ value & $\begin{array}{c}\text { Number of } \\
\text { implants }\end{array}$ & $\begin{array}{c}\text { Mean Papillary } \\
\text { changes in mm (SD) }\end{array}$ & $P$ value \\
\hline Flap & 49 & $0.37(0.04)$ & \multirow[t]{2}{*}{0.46} & 49 & $0.22(0.21)$ & \multirow[t]{2}{*}{0.80} \\
\hline Flapless & 269 & $0.26(0.42)$ & & 269 & $0.27(0.29)$ & \\
\hline Thin Biotype & 31 & $0.48(0.88)$ & \multirow[t]{2}{*}{0.64} & 23 & $0.1(0.14)$ & \multirow[t]{2}{*}{0.45} \\
\hline Thick Biotype & 185 & $0.20(0.31)$ & & 173 & $0.22(0.31)$ & \\
\hline $\begin{array}{c}\text { Bone graft with } \\
\text { SCTG }\end{array}$ & 30 & $-0.04(0.12)$ & \multirow[t]{2}{*}{0.06} & 1 & 1 & \multirow[t]{2}{*}{ / } \\
\hline Bone graft only & 189 & $0.32(0.29)$ & & 1 & 1 & \\
\hline
\end{tabular}

Table 4.

Frequency of advanced soft tissue recession ( $>1 \mathrm{~mm}$ gingival recession) and aesthetic failures $(\mathrm{PES}<7)$

\begin{tabular}{|c|c|c|c|c|}
\hline Authors & Number of implants & $\begin{array}{l}\text { Mean Follow-up } \\
\text { (months) }\end{array}$ & $\begin{array}{c}\text { Midfacial Recession (>1 } \\
\text { mm) }\end{array}$ & $\begin{array}{c}\text { Aesthetic Failures (PES }< \\
\text { 7) }\end{array}$ \\
\hline 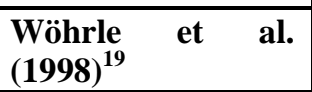 & 14 & 22 & $14.3 \%$ & 1 \\
\hline $\begin{array}{lll}\text { Cosyn } & \text { et } & \text { al. } \\
(2011)^{29} & & \end{array}$ & 25 & 36 & $8 \%$ & $16 \%$ \\
\hline Raes et al. (2013) & 16 & 12 & $7 \%$ & $10 \%$ \\
\hline $\begin{array}{l}\text { Malchiodi et al. } \\
(2013)^{34}\end{array}$ & 64 & 36 & $12.5 \%$ & \\
\hline Weighted Mean & & & $11.02 \%$ & $11.21 \%$ \\
\hline
\end{tabular}




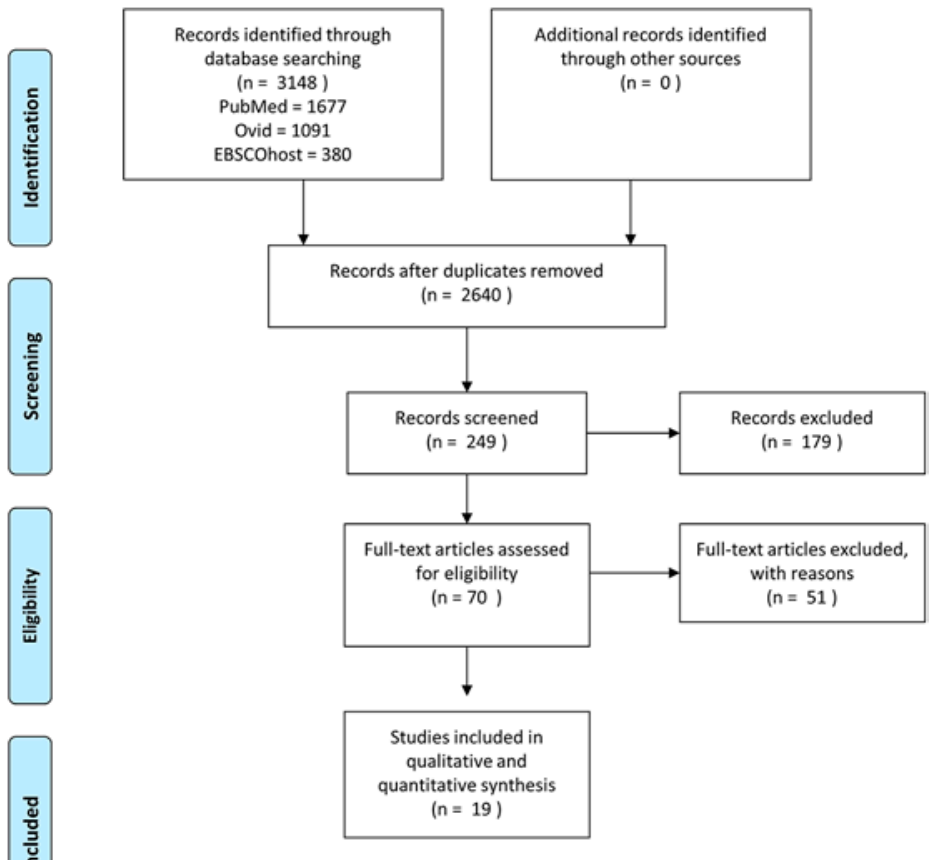

